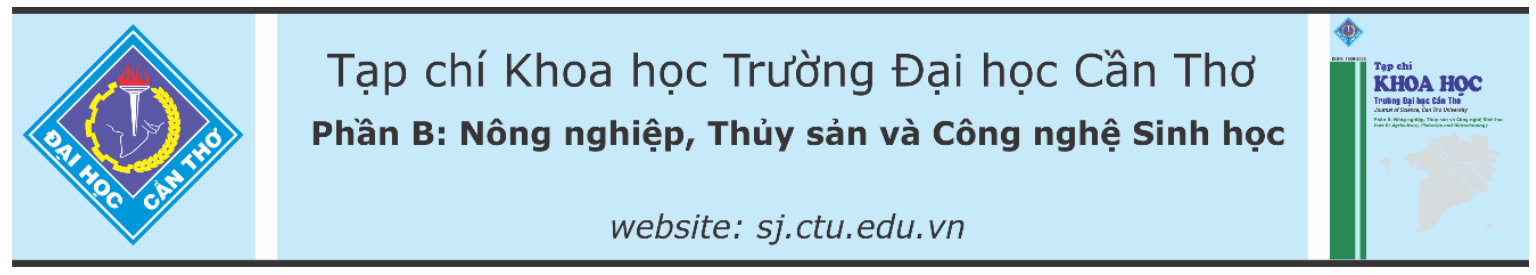

DOI:10.22144/ctu.jvn.2021.158

\title{
KHẢO SÁT ĐẶC ĐIỂM SINH TRƯởNG VÀ CÁU TRÚC GIẢI PHÃ̃ CỦA CỎ LÔNG TÂY (Brachiaria mutica) ĐƯợC TRỒNG TRONG NHÀ LƯớI
}

\author{
Phùng Thị Hằng ${ }^{1 *}$, Nguyễn Khởi Nghĩa ${ }^{2}$ và Hồ Thanh Thâm ${ }^{2}$ \\ ${ }^{1}$ Khoa Su phạm, Truờng Đại học Cần Tho \\ ${ }^{2}$ Khoa Nông nghiệp, Truờng Đại học Cần Tho \\ *Nguời chịu trách nhiệm về bài viết: Phùng Thị Hằng (email: pthang@ctu.edu.vn)
}

\section{Thông tin chung:}

Ngày nhận bài: $28 / 07 / 2021$

Ngày nhận bài sưa: 26/09/2021

Ngày duyệt đăng: 29/10/2021

\section{Title:}

A survey on growth characteristics and anatomical structure of Brachiaria mutica growing under greenhouse conditions

\section{Tù khóa:}

Cấu trúc giải phẫu, cỏ Lông tây (Brachiaria mutica), đặc điểm sinh truơong

\section{Keywords:}

Anatomical structure, growth characteristics, Para grass (Brachiaria mutica)

\begin{abstract}
The experiment was aimed at investigating the growth and anatomical characteristics of Brachiaria mutica (B. mutica). The experiment was designed in completely randomized design with 7 treatments $(T): T 1$ (10 days), T2 (15 days), T3 (20 days), T4 (30 days), T5 (40 days), T6 (50 days) and $T 7$ (60 days). The growth and development of $B$. mutica at three different stages: (1) the budding stage from $T 1$ to $T 3$, in this period the plant concentrates on shoot regeneration; (2) the period of elongation of internodes and increase of leaf area from T4 to T6, which is the stage of strong growth, including height, stem diameter, length and width of leaves; (3) slow growth stage from $T 7$ (60 days) onwards, at this stage leaf area stops growing. The results of microsurgery showed that in T7, the number of cells walls impregnated with lignin, the primary substance comprise of wood was achieved the highest. The structures of tissues with insoluble fiber such as sclerenchyma and collenchyma of stem in T2 and T4 were similar and lower than in T7. The anatomical images of leaves in T7 also showed a higher number of schlerenchyma as compared with $T 2$ and T4, resulting in a decrease of tissue area capable of anabolic/photosynthetic processes. The optimal combination of yield and quality of B. mutica needs to be considered during the period from 30-60 days after cutting.
\end{abstract}

\section{TÓM TẮT}

Thi nghiệm được tiến hành nhằm khảo sát đặc điểm sinh trưởng và giải phẫu của cỏ Lông tây (Brachiaria mutica). Thí nghiệm được bố trí hoàn toàn ngẫu nhiên với 7 nghiệm thức: T1 (10 ngày), T2 (15 ngày), T3 (20 ngày), T4 (30 ngày), T5 (40 ngày), T6 (50 ngày) và T7 (60 ngày). Sinh trương và phát triển của cỏ Lông tây chia làm ba giai đoạn: (1) Giai đoạn sinh chồi tù T1 đến T3, trong giai đoạn này cây tập trung cho tái sinh chồi; (2) Giai đoạn kéo dài lóng và tăng diện tích lá tù̀ T4 đến T6, là giai đoạn cây phát triển mạnh cả về chiều cao, đường kính thân và dài rộng lá; và (3) Giai đoạn sinh trương chậm tù T7 (60 ngày) trở về sau, tại giai đoạn này diện tích lá ngung tăng trương. Kết quả khảo sát vi phẫu cho thấy ở nghiệm thức T7 số luợng tế bào có vách tẩm thêm lignin (chất tạo chất gố) nhiều nhất. Cấu trúc các loại mô tạo chất xơ nhu mô dầy, mô cúng của thân cỏ Lông tây ở nghiệm thức T2 và T4 tuoong đương nhau và thấp hơn so với nghiệm thức T7. Hình ảnh giải phẫu của lá ở nghiệm thức 77 cũng cho thấy số lương mô cưng cao hơn so với nghiệm thức T2 và T4 làm cho diện tích mô có khả năng đồng hóa/quang hợp giảm. Sụ kết hợp hài hoà giữa năng suất và chất luợng của cỏ Lông tây cần được xem xét trong giai đoạn tù 30 đến 60 ngày sau khi cắt. 


\section{1. ĐẶT VẤN ĐỀ}

Chăn nuôi Việt Nam đang phát triển mạnh trong những năm gần đây và góp phần to lớn vào tốc độ tăng trưởng chung của ngành nông nghiệp. Theo Cục Chăn nuôi (2020) ngành chăn nuôi luôn duy trì mức tăng trưởng bình quân 4,5-5\%/năm (20112015) và tỷ trọng chăn nuôi trong ngành nông nghiệp đạt $32 \%$ năm 2018. Khi đàn gia súc tăng nhanh, nhu cầu thức ăn xanh trong khẩu phần ăn hằng ngày của chúng cũng ngày càng tăng (Từ Trung Kiên và ctv., 2011). Tuy nhiên, dưới tác động của biến đổi khí hậu, quá trình đô thị hoá diện tích đất canh tác và đồng cỏ tự nhiên bị thu hẹp. Mặt khác, phụ phẩm nông nghiệp đang bị nhiều loại gia súc, gia cầm khác cạnh tranh một cách gay gắt dẫn đến nguồn thức ăn thô xanh của gia súc nhai lại đang ít dần (Trần Đại Nghĩa, 2018). Vì vậy, mặc dù chăn nuôi gia súc nhai lại mang đến nguồn thu nhập cao, nhưng diện tích trồng cỏ không đáng kể so với tốc độ phát triển đàn gia súc, nhiều hộ chăn nuôi đã không thể tăng đàn, do không đáp ứng tốt nguồn thức ăn xanh cho chúng (Lê Đức Ngoan và ctv., 2006).

Cỏ Lông tây (Brachiaria mutica) được xem là một trong những loại cỏ thích hợp với nhiều sinh cảnh khác nhau, từ độ cao $1.000 \mathrm{~m}$ (so với mực nước biển) đến những nơi đầm lầy (chịu ngập đến $60 \mathrm{~cm}$ ), sống được ở các loại đất đỏ, đất mặn, đất phèn và thích hợp nhất là đất phù sa (Lê Đức Ngoan và ctv., 2006). Ngoài ra, cỏ Lông tây còn có các ưu điểm khác như khả năng tái sinh cao, thành phần hóa học và giá trị dinh dưỡng tốt (Dong et al., 2008; Serra et al., 1996), do đó cỏ Lông tây được trồng khá phổ biến ở các tỉnh Đồng bằng sông Cửu Long, giải quyết cho các khó khăn về nguồn thức ăn xanh cho gia súc (Nguyễn Nhựt Xuân Dung và ctv., 2007). Các nghiên cứu về cỏ Lông tây cho thấy thành phần hoá học và giá trị dinh dưỡng có sự khác nhau giữa lá và thân. Hàm lượng protein thô của cỏ biến động ở từng giai đoạn và từng bộ phận (Lê Đức Ngoan và ctv., 2006). Các nhân tố có thể ảnh hưởng đến chất lượng cỏ bao gồm ánh sáng (Rumokoy \& Toar, 2014; Sumolang et al., 2020), khoảng cách trồng, thời gian thu hoạch (Lưu Hữu Mãnh và ctv., 2007; Zemene et al., 2020) và dinh dưỡng trong đất trồng (Alam et al., 2015).

Hình thái học thực vật được ứng dụng vào nông nghiệp từ rất lâu đời, việc nghiên cứu về hình thái giải phẫu cung cấp cơ sở hợp lý để làm rõ mối quan hệ giữa các đặc tính bên trong và bên ngoài của một sinh vật, cung cấp cơ sở lý thuyết để hiểu được sự hình thành của các cấu trúc hữu cơ (Neville \& Marbora, 2007). Các cấu trúc giải phẫu trong giai đoạn phát triển có thể giải thích và minh chứng cho sự tích luỹ các chất dự trữ trong cây giúp ích cho quá trình trồng trọt (Crang et al., 2018). Các nghiên cứu trên thế giới về đặc điểm hình thái, giải phẫu và sinh lý liên quan đến sinh trưởng và dinh dưỡng của các nhóm cỏ trồng và nhiều loại cây khác nhau cũng được khảo sát như ở lúa, chuối (Dwari \& Mondal, 2011; Lopes et al., 2011; Sumardi \& Wulandari, 2010; Wu et al., 2011). Vì vậy, nghiên cứu các đặc điểm về sinh trưởng và giải phẫu của cỏ Lông tây được tiến hành nhằm cung cấp thêm dữ liệu về đặc điểm nông học và giải phẫu; tìm mối quan hệ giữa sinh trưởng, phát triển và cấu trúc bên trong giúp cho việc trồng, thu hoạch, nâng cao năng suất và chất lượng cỏ Lông tây làm thức ăn cho gia súc nhai lại một cách hợp lý và hiệu quả hơn.

\section{VẬT LIẾU VÀ PHƯƠNG PHÁP}

\subsection{Thời gian và địa điểm}

Thí nghiệm được tiến hành từ tháng 3 đến tháng 12 năm 2020 tại Vườn thực nghiệm Khoa Sư phạm. Mẫu cỏ tươi sau khi cắt được giải phẫu tại Phòng thí nghiệm Sinh lý thực vật, Bộ môn Sư phạm Sinh học, Khoa Sư phạm, Trường Đại học Cần Thơ.

\subsection{Chọn hom, chuẩn bị đất, bố trí thí nghiệm và thu thập các chỉ tiêu sinh trưởng}

Hom cỏ và mẫu đất được lấy từ đồng cỏ của hộ nông dân ở xã Thuận Thới, huyện Trà Ôn, tỉnh Vĩnh Long. Hom được chọn là những cây trưởng thành, to, tươi, loại bỏ những đoạn quá non hay quá già, được cắt thành các đoạn dài khoảng $15-20 \mathrm{~cm}$, đảm bảo mỗi hom có 2-3 mắt. Hom được tưới nước ẩm ủ qua đêm trước khi đem trồng (Lê Đức Ngoan và ctv., 2006). Đất thí nghiệm được thu ở nhiều vị trí khác nhau trên mặt ruộng ở độ sâu 0-20 cm, sau đó được đem về vườn thực nghiệm Khoa Sư phạm để phơi khô tự nhiên, tránh ánh nắng mặt trời chiếu trực tiếp (Lưu Hữu Mãnh và ctv., 2007). Đất được băm nhỏ và trộn đều trước khi cho vào từng chậu thí nghiệm, đồng thời tiến hành thu mẫu đất đại diện để phân tích một số đặc tính hóa học đất thí nghiệm gồm $\mathrm{pH}, \mathrm{EC}$ bão hòa, chất hữu cơ, đạm tổng số $\left(\mathrm{N}_{\mathrm{ts}}\right)$, lân tồng số $\left(\mathrm{P}_{\mathrm{ts}}\right)$, kali tổng số $\left(\mathrm{K}_{\mathrm{ts}}\right), \mathrm{NH}_{4}{ }^{+}, \mathrm{NO}_{3}^{-}, \mathrm{P}$ dễ tiêu và kali trao đổi. Các đặc tính đất này được phân tích tại phòng thí nghiệm hóa học đất thuộc Bộ môn Khoa học Đất, Khoa Nông nghiệp, Trường Đại học Cần Thơ. Đặc tính đất thí nghiệm được trình bày trong Bảng 1. 


\section{Bảng 1. Đặc tính hóa học đất thí nghiệm}

\begin{tabular}{lc}
\hline Đặc tính đất & Kết quả \\
\hline $\mathrm{pH}_{\mathrm{H} 2 \mathrm{O}}$ & 5,00 \\
EC bão hòa $(\mathrm{mS} / \mathrm{cm})$ & 0,56 \\
Chất hữu cơ $(\%)$ & 5,32 \\
$\mathrm{~N}_{\mathrm{ts}}(\% \mathrm{~N})$ & 0,15 \\
$\mathrm{NH}_{4}{ }^{+}-\mathrm{N}(\mathrm{mg} / \mathrm{kg})$ & 33,0 \\
$\mathrm{NO}_{3}^{-}-\mathrm{N}(\mathrm{mg} / \mathrm{kg})$ & 0,11 \\
$\mathrm{P}_{\mathrm{ts}}\left(\% \mathrm{P}_{2} \mathrm{O}_{5}\right)$ & 0,05 \\
$\mathrm{P}$ dễ tiêu $(\mathrm{mg} / \mathrm{kg})$ & 1,54 \\
$\mathrm{~K}$ tổng $\left(\% \mathrm{~K}_{2} \mathrm{O}\right)$ & 1,60 \\
$\mathrm{~K}$ trao đồi $(\mathrm{meq} / 100 \mathrm{~g})$ & 0,16 \\
\hline
\end{tabular}

Thí nghiệm được bố trí theo phương pháp của Lopes et al. (2011) có bổ sung. Thời gian thu thập các chỉ tiêu được lựa chọn để khảo sát quá trình sinh trưởng là 5 ngày; kết hợp với thời gian khảo sát năng suất là 10 ngày, 7 nghiệm thức tương ứng với các giai đoạn khác nhau được bố trí hoàn toàn ngẫu nhiên với 3 lần lặp lại gồm T1 (10 ngày), T2 (15 ngày), T3 (20 ngày), T4 (30 ngày), T5 (40 ngày), T6 (50 ngày) và $T 7$ (60 ngày). Cỏ ở từng nghiệm thức được bố trí trồng trong chậu có kích thước $60 \mathrm{~cm} \times$ $40 \mathrm{~cm}$, mỗi chậu gồm 6 hom cỏ. Cỏ được trồng theo hộc, mỗi hộc 1 hom, mỗi hom cách nhau $10 \mathrm{~cm}$, trồng nghiêng một góc $45^{\circ}$. Hom được lấp kín đất với một lớp $2-3 \mathrm{~cm}$ và đảm bảo mắt ở mỗi hom tiếp xúc với đất. Tưới nước hai lần mỗi ngày vào $8 \mathrm{~h}$ sáng và $4 \mathrm{~h}$ chiều.

Sau khi trồng cỏ Lông tây 45 ngày, cỏ được cắt và không lấy chỉ tiêu, bắt đầu lấy chỉ tiêu lứa tiếp theo. Các chỉ tiêu được lấy ở các thời điểm (nghiệm thức) được trình bày ở Bảng 2 .

Bảng 2. Các chỉ tiêu và cách thu thập số liệu sinh trưởng cỏ Lông tây trong thí nghiệm

\begin{tabular}{|c|c|c|}
\hline Chỉ tiêu & \multicolumn{2}{|l|}{ Cách thu thập số liệu } \\
\hline $\begin{array}{l}\text { Chiều cao thân } \\
(\mathrm{CCT})(\mathrm{cm})\end{array}$ & \multicolumn{2}{|c|}{$\begin{array}{l}\text { Đo từ mặt đất đến chỗ tận cùng thân phía trên của cây cao nhất trong bụi không tính } \\
\text { phần ngọn lá. }\end{array}$} \\
\hline $\begin{array}{l}\text { Chiều cao cây } \\
(\mathrm{CCC})(\mathrm{cm})\end{array}$ & \multicolumn{2}{|c|}{ Đo từ mặt đất đến chỗ tận cùng khi vuốt thẳng lá cỏ cao nhất của bụi. } \\
\hline Số chồi (chồi) & \multicolumn{2}{|l|}{ Đếm tổng số chồi/bụi. } \\
\hline $\begin{array}{l}\text { Đường } \\
\text { (ĐKT) }\end{array}$ & \multicolumn{2}{|l|}{ Đo phần rộng nhất của thân cây } \\
\hline Chiều dài lá $(\mathrm{cm})$ & \multicolumn{2}{|c|}{$\begin{array}{l}\text { Chọn lá thứ } 3 \text { tính từ lá trong cùng ra của cây cao nhất trong bụi. Đo từ cuống lá } \\
\text { đên ngọn lá. }\end{array}$} \\
\hline Chiều rộng lá (cm) & \multicolumn{2}{|c|}{$\begin{array}{l}\text { Chọn lá thứ } 3 \text { tính từ lá trong cùng ra của cây cao nhất trong bụi. Đo chiều rộng của } \\
\text { phần rộng nhất của lá. }\end{array}$} \\
\hline $\begin{array}{l}\text { Năng suất chất } \\
\text { xanh (tấn/ha/năm) }\end{array}$ & \multicolumn{2}{|c|}{ Cắt sinh khối cỏ cách mặt đất $5-7 \mathrm{~cm}$, cân toàn bộ cỏ của từng ô nghiệm thức. } \\
\hline \multicolumn{2}{|c|}{$\begin{array}{l}\text { 2.3. Phương pháp và cách thu thập các chỉ } \\
\text { tiêu giải phẩu thân và lá cỏ Lông tây }\end{array}$} & $\begin{array}{l}\text { tiêu bản tạm thời và quan sát bằng kính hiển } \mathrm{v} \\
\text { quang học (Olympus CX23) có camera }(\mathrm{RS}-500 \mathrm{C}\end{array}$ \\
\hline \multicolumn{2}{|c|}{$\begin{array}{l}\text { Chỉ tiêu giải phẫu lấy ngẫu nhiên ở các nghiệm } \\
\text { hức T2 (15 ngày), T4 (30 ngày) và T7 (60 ngày) } \\
\text { Bridgemohan et al., 2015). Mẫu giải phẫu được cố } \\
\text { tịnh ngay sau khi cắt khỏi cây. Vị trí giải phẫu gồm } \\
\text { thân là lóng thứ } 3 \text { (tính từ ngọn) và ở lá gồm các } \\
\text { ị trí mép lá và gân lá của lá thứ ba (từ ngọn xuống) } \\
\text { tược chọn để so sánh cấu trúc giải phẫu (Taiz \& } \\
\text { Zeiger, 2003). Mẫu được cắt mỏng bằng tay theo tiết } \\
\text { liện ngang, tiến hành các lát cắt liên tiếp nhau (10 } \\
\text { ất cắt liên tiếp) bằng dao lam sắc. Mẫu sau khi cắt } \\
\text { tược nhuộm kép với Carmin aluné - vert d'iod }\end{array}$} & $\begin{array}{l}\text { (Upton et al., 2016). Các chỉ tiêu giải phẫu thực hiệr } \\
\text { đo } 3 \text { vị trí khác nhau trên cùng một vi mẫu để tính } \\
\text { số trung bình. Mẫu lấy chỉ tiêu được đo bằng phầr } \\
\text { mềm S-EYE với các trắc vi vật kính X10 (đối vớ } \\
\text { diện tích bó libe-gỗ) và X40 (đối với các loại mó } \\
\text { khác). Ngoại trừ bó libe-gỗ được đo diện tích, cá } \\
\text { mô còn lại ở thân và lá được đo kích thước (độ dày } \\
\text { hoặc đường kính) tế bào hoặc mô theo hướng tiế } \\
\text { tuyến vuông góc với trục thân hoặc chiều dọc lá. Cá } \\
\text { loại mô khảo sát và phương pháp đo được biểu diễ̂r } \\
\text { ở Bảng } 3 \text {. }\end{array}$ \\
\hline
\end{tabular}


Bảng 3. Các chỉ tiêu và phương pháp đo số liệu giải phẫu trên cỏ Lông tây

\begin{tabular}{ll}
\hline Chỉ tiêu & Cách thu thập số liệu \\
\hline $\begin{array}{l}\text { Tế bào biểu bì thân } \\
(\mu \mathrm{m})\end{array}$ & Đo độ dày lớp tế bào ngoài cùng của thân \\
\hline $\begin{array}{l}\text { Mô mềm vùng vỏ thân } \\
(\mu \mathrm{m})\end{array}$ & $\begin{array}{l}\text { Đo kích thước của vùng mô mềm vỏ (giới hạn từ vách của lớp tế bào biểu bì } \\
\text { đến mép ngoài của vùng có mô cứng) }\end{array}$ \\
\hline Mô cứng thân $(\mu \mathrm{m})$ & $\begin{array}{l}\text { Đo độ dày nhóm tế bào có vách màu xanh đậm (sau khi nhuộm kép), tiếp giáp } \\
\text { với mô mềm vỏ. }\end{array}$ \\
\hline $\begin{array}{l}\text { Mô mềm tẩm thêm chất } \\
\text { gố vùng trụ thân }(\mu \mathrm{m})\end{array}$ & $\begin{array}{l}\text { Đo kích thước nhóm tế bào mô mềm có vách đã tẩm thêm chất gỗ (màu xanh } \\
\text { sau khi nhuộm kép) của vùng trụ trung tâm thân, thường có vị trí bên trong mô } \\
\text { cưng thân. }\end{array}$ \\
\hline Hạ bì lá $(\mu \mathrm{m})$ & Đo đường kính dọc của các tế bào hình cánh quạt dưới biểu bì lá. \\
\hline Mô cứng lá $(\mu \mathrm{m})$ & $\begin{array}{l}\text { Đo kích thước nhóm tế bào có vách dày (có màu xanh sau khi nhuộm) có trí } \\
\text { ở giữa biểu bì và các bó mạch. }\end{array}$ \\
\hline Mô cứng ở mép lá ( $\mu \mathrm{m})$ & $\begin{array}{l}\text { Đo kích thước nhóm tế bào có vách dày (bắt màu xanh khi nhuộm kép) tại vị } \\
\text { trí chóp của mép lá. }\end{array}$ \\
\hline $\begin{array}{l}\text { Diện tích bó libe-gỗ } \\
\text { thân/lá }\left(\mu \mathrm{m}^{2}\right)\end{array}$ & $\begin{array}{l}\text { Đo diện tích xung quanh bó libe gỗ của thân và lá, tính cả lớp tế bào bao bên } \\
\text { ngoài. }\end{array}$ \\
\hline
\end{tabular}

Số liệu được xử lí trên phần mềm Microsoft Excel 2013 và được phân tích bằng phần mềm SPSS. Dùng phép thử $\mathrm{F}$ để xác định sự khác biệt giữa các nghiệm, khác biệt ý nghĩa thống kê khi so sánh với nhau $(\mathrm{p}<0,05)$. Phép thử Duncan được sử dụng để so sánh trung bình giữa các nghiệm thức.

\section{KẾT QUẢ VÀ THẢO LUẬN}

\subsection{Xác định các giai đoạn sinh trưởng của cỏ Lông tây thông qua các đặc điểm nông học và năng suất}

Việc xác định đúng các giai đoạn của quá sinh trưởng và phát triển của cây làm thức ăn gia súc rất quan trọng cho việc thu hoạch và chăn thả. Các giai đoạn phát triển thể hiện qua các đặc điểm hình thái (có thể đo đếm được) và có mối tương quan với tỉ lệ hàm lượng chất thô xanh cụ thể là năng suất (không dễ để dự đoán) (Frank, 1996). Chiều cao, tốc độ tái sinh và khả năng đẻ nhánh là các chỉ tiêu quan trọng trong đánh giá khả năng sinh trưởng và phát triển của cây làm thức ăn cho gia súc (Nguyễn Thị Hòa Bình và ctv., 2017). Năng suất là yếu tố cơ bản của một giống, đây cũng là kết quả cuối cùng của quá trình sinh trưởng phát triển, tích lũy và tổng hợp chất hữu cơ (Phan Thị Phương Nhi \& Trần Thị Hương Sen, 2017). Vì vậy, trong nghiên cứu này, các chỉ tiêu về số chồi (tốc độ tái sinh), đặc điểm sinh trưởng của thân $(\mathrm{CCC}, \mathrm{CCT}, \mathrm{DKT})$, đặc điểm sinh trưởng của lá (chiều dài, chiều rộng lá) và năng suất đã được khảo sát.

Khả năng tái sinh (tốc độ sinh chồi) của các nghiệm thức được thể hiện ở Bảng 4 . Kết quả thống kê cho thấy từ nghiệm thức $\mathrm{T} 1$ đến nghiệm thức $\mathrm{T} 7$ có sự tăng dần về số chồi (sự khác biệt ở mức ý nghĩa thống kê 5\%).

Bảng 4. Số chồi (chồi/bụi) của cỏ Lông tây

\begin{tabular}{lr}
\hline Nghiệm thức & Số chồi/bụi \pm SD \\
\hline T1 & $4,33 \pm 1,53^{\mathrm{d}}$ \\
T2 & $5,00 \pm 1,00^{\mathrm{d}}$ \\
T3 & $6,00 \pm 2,00^{\mathrm{d}}$ \\
T4 & $11,67 \pm 1,53^{\mathrm{c}}$ \\
T5 & $14,33 \pm 3,21^{\mathrm{bc}}$ \\
T6 & $17,67 \pm 4,63^{\mathrm{b}}$ \\
T7 & $22,00 \pm 1,00^{\mathrm{a}}$ \\
\hline F & $*$ \\
CV $(\%)$ & 4,3 \\
\hline
\end{tabular}

(*) khác biệt ở múc ý nghĩa thống kê 5\%. Trong cùng 1 cột, các chũ số theo sau số có cùng mẫu tư giống nhau thì khác biệt không có ý nghĩa theo phép thử Duncan.

T1: Giai đoạn 10 ngày sau khi cắt, T2: Giai đoạn 15 ngày sau khi cắt, T3: Giai đoạn 20 ngày sau khi cắt, T4: Giai đoạn 30 ngày sau khi cắt, T5: Giai đoạn 40 ngày sau khi cắt, T6: Giai đoạn 50 ngày sau khi cắt, T7: Giai đoạn 60 ngày sau khi cắt.

CV (\%): hệ số biến thiên, SD: độ lệch chuẩn.

Tốc độ nảy chồi hay còn gọi là tái sinh chồi có nhiều ý nghĩa quan trọng đối với cây trồng, số chồi càng cao thì năng suất chất xanh càng cao và thể hiện khả năng thích nghi tốt của cây trồng với điều kiện đất đai và môi trường sống (Evert et al., 2013; Frank, 1996). Kết quả thực nghiệm trên cỏ Lông tây cho thấy ở các nghiệm thức T1, T2, T3 (10 đến 20 ngày sau khi cắt) có nảy chồi dao động từ 4 chồi đến 6 chồi. Sau giai đoạn dưỡng hom (45 ngày), cỏ sẽ được cắt chỉ giữ 2 đến 3 mắt tính từ bề mặt đất lên (số chồi trên nhánh mới của hom), như vậy với số 
lượng 4 đến 6 chồi/hom sau 10 đến 20 ngày (mỗi mắt trung bình đều có 1 chồi) cho thấy khả năng nảy chổi và tốc độ phân nhánh ở cỏ Lông tây là khá cao. Điều này cũng cho thấy điều kiện trồng đáp ứng nhu cầu phát triển của cỏ Lông tây, bộ rễ của cỏ Lông tây sau 45 ngày đã phát triển tốt, hấp thu được dưỡng chất từ đất (Rechenthin, 1956). Ở nghiệm thức T4 (30 ngày) đến nghiệm thức $\mathrm{T} 7$ (60 ngày), số chồi tăng lên từ 11,67 chồi/bụi đến 22 chồi/bụi. Số liệu này tương ứng với kết quả thực nghiệm của Zemene et al. (2020) trồng cỏ Lông tây trên đất vườn tại Ethiopia, thời điểm 60 ngày là 35,2 chồi và 48 chồi với khoảng cách trồng từ $15 \mathrm{~cm}$ đến $45 \mathrm{~cm}$ và số lượng hom ghim đầu tiên là 2 hom/1 hộc. Số liệu thống kê cho thấy số lượng chồi tăng liên tục, chứng tỏ khả năng tái sinh của cỏ Lông tây khá mạnh, tất cả các mắt (đỉnh sinh trưởng) trên lóng của cỏ đều có khả năng tạo nhánh mới. Đánh giá bằng số liệu thống kê và độ tin cậy giữa các nghiệm thức cho thấy nghiệm thức $\mathrm{T} 1, \mathrm{~T} 2$ và $\mathrm{T} 3$ không có khác biệt thống kê, tương tự giữa nghiệm thức $\mathrm{T} 4$ và $\mathrm{T} 5$; giữa $\mathrm{T} 5$ và $\mathrm{T} 6$ cũng không có khác biệt. Tuy nhiên, nếu phân chia thành các giai đoạn $10-20$ ngày $(\mathrm{T} 1, \mathrm{~T} 2$, $\mathrm{T} 3), 30$ đến 50 ngày $(\mathrm{T} 4, \mathrm{~T} 5, \mathrm{~T} 6)$ và giai đoạn 60 ngày (T7) thì có sự khác biệt ở độ tin cậy $95 \%$. Như vậy, kết quả Bảng 4 cho thấy có thể chia khả năng tái sinh thành ba giai đoạn sinh trưởng: giai đoạn thứ nhất sau khi cắt đến 20 ngày, giai đoạn thứ hai từ 30 đến 50 ngày và giai đoạn thứ ba từ 60 ngày trở về sau. Đối với cỏ Lông tây trồng trong chậu trong thời gian 60 ngày, số chồi tî̉ lệ thuận với thời gian trồng.

\section{2. Đặc điểm sinh trưởng của thân}

Các đặc điểm sinh trưởng của thân gồm $\mathrm{CCC}$, $\mathrm{CCT}$ và $\mathrm{ĐKT}$ được khảo sát và kết quả được trình bày ở Bảng 5 . Có thể thấy $\mathrm{CCC}$ và $\mathrm{CCT}$ tăng dần từ nghiệm thức $\mathrm{T} 1$ (10 ngày sau khi cắt) đến nghiệm thức $\mathrm{T} 7$ (60 ngày sau khi cắt), lần lượt tương ứng từ 50,06 đến $159,33 \mathrm{~cm}$ và từ 32,17 đến $142,78 \mathrm{~cm}$, các nghiệm thức có sự khác biệt ý nghĩa thống kê $(\mathrm{p}<0,05)$ khi so sánh với nhau. CCC ở nghiệm thức $\mathrm{T} 7$ phù hợp với đặc điểm mô tả về cỏ Lông tây của Lê Đức Ngoan và ctv. (2006), chiều cao của cỏ có thể đạt đến 1,5 m. CCC của nghiệm thức T7 cao hơn so với kết quả nghiên cứu của Lưu Hữu Mãnh và ctv. (2007) trồng tại đất vườn với khoảng cách $20 \times 20 \mathrm{~cm}$ và tương đương với $\mathrm{CCC}$ thu hoạch ở thời điểm 70 ngày sau khi cắt với khoảng cách $20 \times 30$ $\mathrm{cm}$. Theo Rechenthin (1956) và Taiz and Zeige (2003), chiều cao là thước đo đánh giá tốc độ sinh trưởng và phát triển của cây trồng. Xét về chỉ tiêu $\mathrm{CCC}, \mathrm{CCT}$ được trình bày ở Bảng 5 và dựa vào mức độ khác biệt ý nghĩa thống kê giữa các nghiệm thức cho thấy sự phát triển $\mathrm{CCC}$ và $\mathrm{CCT}$ của cỏ Lông tây cũng có thể được chia làm ba giai đoạn như sau: giai đoạn 20 ngày sau khi cắt, giai đoạn 30 đến 50 ngày và giai đoạn từ ngày 60 trở về sau. Như vậy, giai đoạn 30 đến 50 ngày $(\mathrm{T} 4, \mathrm{~T} 5$ và $\mathrm{T} 6)$ được xem là giai đoạn phát triển mạnh của cơ quan sinh dưỡng; trong khi giai đoạn từ 60 ngày trở về sau $(\mathrm{T} 7)$, cỏ phát triển vượt bậc về chiều cao và đường kính thân. Tuy nhiên, cần có sự kết hợp với các chỉ tiêu khác như đặc điểm sinh trưởng và đặc điểm giải phẫu để đánh giá giai đoạn phù hợp trong thu hoạch cỏ.

Bảng 5. Chiều cao $(\mathrm{cm})$ và ĐKT $(\mathrm{cm})$ của cỏ Lông tây

\begin{tabular}{lrrr}
\hline Nghiệm thức & Cao thân \pm SD & Cao cây \pm SD & Đường kính \pm SD \\
\hline T1 & $32,17 \pm 0,44^{\mathrm{e}}$ & $50,06 \pm 8,39^{\mathrm{d}}$ & $0,31 \pm 2,00^{\mathrm{bc}}$ \\
T2 & $44,22 \pm 9,64^{\mathrm{de}}$ & $62,94 \pm 10,55^{\mathrm{cd}}$ & $0,28 \pm 1,00^{\mathrm{c}}$ \\
T3 & $51,78 \pm 4,76^{\mathrm{cde}}$ & $66,00 \pm 3,06^{\mathrm{cd}}$ & $0,36 \pm 1,53^{\mathrm{bc}}$ \\
T4 & $72,22 \pm 19,14^{\mathrm{bcd}}$ & $90,34 \pm 21,73^{\mathrm{bc}}$ & $0,42 \pm 1,53^{\mathrm{b}}$ \\
T5 & $77,39 \pm 14,83^{\mathrm{bc}}$ & $96,22 \pm 12,93^{\mathrm{b}}$ & $0,55 \pm 3,21^{\mathrm{a}}$ \\
T6 & $97,33 \pm 13,62^{\mathrm{b}}$ & $113,56 \pm 13,09^{\mathrm{b}}$ & $0,61 \pm 4,63^{\mathrm{a}}$ \\
T7 & $142,78 \pm 26,22^{\mathrm{a}}$ & $159,33 \pm 24,89^{\mathrm{a}}$ & $0,63 \pm 1,00^{\mathrm{a}}$ \\
F & $*$ & $*$ & $*$ \\
CV $(\%)$ & 3,4 & 3,8 & 4,1 \\
\hline
\end{tabular}

(*) khác biệt ở mức ý nghĩa thống kê $5 \%$. Trong cùng 1 cột, các chũ số theo sau số có cùng mẫu tụ giống nhau thì khác biệt không có ý nghĩa theo phép thử Duncan.

T1: Giai đoạn 10 ngày sau khi cắt, T2: Giai đoạn 15 ngày sau khi cắt, T3: Giai đoạn 20 ngày sau khi cắt, T4: Giai đoạn 30 ngày sau khi cắt, T5: Giai đoạn 40 ngày sau khi cắt, T6: Giai đoạn 50 ngày sau khi cắt, T7: Giai đoạn 60 ngày sau khi cắt.

CV (\%): hệ số biến thiên, SD: độ lệch chuẩn.

Xét chỉ tiêu về ĐKT, Bảng 5 cho thấy ĐKT của cỏ Lông tây tăng từ nghiệm thức $\mathrm{T} 1$ đến $\mathrm{T} 7$ (từ 0,31 đến $0,63 \mathrm{~cm}$ ). Tuy nhiên, ĐKT tăng không đều, ở các nghiệm thức từ $\mathrm{T} 1$ đến $\mathrm{T} 4 \mathrm{ĐKT}$ dao động trong 
khoảng $0,28 \mathrm{~cm}$ đến $0,42 \mathrm{~cm}$, trung bình tăng khoảng $0,06 \mathrm{~cm}$ lên đến $0,13 \mathrm{~cm}$, nhưng từ nghiệm thức $\mathrm{T} 5$ đến $\mathrm{T} 7$ thì ĐKT tăng rất chậm, chỉ tăng được $0,02 \mathrm{~cm}$. Điều này có thể giải thích là do Cỏ Lông tây là cây thân thảo và thuộc nhóm một lá mầm, không có cấu trúc thứ cấp, cây có xu hướng phát triển chiều dài, không phát triển chiều ngang (Dwari \& Mondal, 2011; NCERT, 2005; Rechenthin, 1956). Như vậy, ở cỏ Lông tây, giai đoạn sau khi cắt đến 40 ngày, thân cây sinh trưởng mạnh kéo theo ĐKT tăng, sau đó sự phát triển về ĐKT sẽ dừng lại. ĐKT là một trong những chỉ tiêu ảnh hưởng đến năng suất của đồng cỏ (Frank, 1996; Rechenthin, 1956). Việc xác định các đặc điểm sinh trưởng và giai đoạn phát triển của thân $(\mathrm{CCC}, \mathrm{CCT}$ và ĐKT) có ý nghĩa quan trọng cho việc xác định thời gian thu hoạch. Đối với cỏ Lông tây, sự sinh trưởng $\mathrm{CCC}$ và $\mathrm{CCT}$ cũng có thể chia ra thành 3 giai đoạn: sau khi cắt 20 ngày, giai đoạn từ 30 đến 50 ngày và giai đoạn từ 60 ngày trở về sau. Tuy nhiên, ĐKT từ giai đoạn 40 ngày sau khi cắt trở về sau cần được lưu ý vì sự tăng trưởng về ĐKT giảm rõ rệt.

\section{3. Đặc điểm sinh trưởng lá và năng suất xanh của cỏ Lông tây}

Lá thực hiện quá trình quang hợp để cung cấp dinh dưỡng và quyết định đến năng suất cây trồng (Nguyễn Bá Lộc, 2011). Các chỉ tiêu về chiều dài lá (CDL) và chiều rộng lá (CRL) cây cỏ Lông tây thí nghiệm được thể hiện ở Bảng 6 .

CDL 10 ngày sau khi cắt (nghiệm thức $\mathrm{T} 1$ ) đạt $31,05 \mathrm{~cm}$, tăng tiếp thêm gần $8 \mathrm{~cm}$ ở nghiệm thức T2 (15 ngày), sau đó ở các nghiệm thức T3, T4, T5, T6 CDL cỏ Lông tây gần như không tăng và đạt giá trị dao động từ $39,61 \mathrm{~cm}$ đến $40,68 \mathrm{~cm}$ và không khác biệt ý nghĩa thống kê $(\mathrm{p}<0,05)$. Đặc biệt, nghiệm thức $\mathrm{T} 7 \mathrm{CDL}$ giảm còn $35,89 \mathrm{~cm}$. Tương tự đối với $\mathrm{CRL}$, ở nghiệm thức $\mathrm{T} 1$ có $\mathrm{CRL}$ thấp nhất là $1,22 \mathrm{~cm}$. Các nghiệm thức còn lại (T2 đến T6) có CRL dao động từ $1,37 \mathrm{~cm}$ đến $1,92 \mathrm{~cm}$, tuy nhiên, giữa các nghiệm thức $\mathrm{T} 2, \mathrm{~T} 3, \mathrm{~T} 4$; cũng như giữa nghiệm thức $\mathrm{T} 5$ và $\mathrm{T} 6$ không khác biệt ý nghĩa thống kê khi so sánh với nhau $(\mathrm{p}>0,05)$. Sau đó, CRL giảm ở nghiệm thức $\mathrm{T} 7$ với giá trị đạt $1,75 \mathrm{~cm}$ và thấp hơn so với nghiệm thức T6. Nghiên cứu của Zemene et al. (2020) tại Ethiopia cho thấy CDL cao nhất của cỏ Lông tây đạt $26,7 \mathrm{~cm}$ tại thời điểm 120 ngày, tại thời điểm 60 ngày, CDL chỉ đạt $20,1 \mathrm{~cm}$. Như vậy, xét về đặc điểm lá có thể thấy ngay sau khi sinh chồi, cây phát triển mạnh hệ thống lá, tăng diện tích để quang hợp, tạo dinh dưỡng cho cây sinh trưởng (Duru \& Ducrocq, 2000). Đối với cỏ Lông tây, thời gian để cây phát triển mạnh hệ thống lá kéo dài khoảng 15 ngày sau khi cắt và sau thời gian này diện tích lá sẽ không tăng thêm nữa.

Bảng 6. Chỉ tiêu sinh trưởng lá $(\mathrm{cm})$ của cỏ Lông tây

\begin{tabular}{|c|c|c|}
\hline Nghiệm thức & Dài lá \pm SD & Rộng lá \pm SD \\
\hline $\mathrm{T} 1$ & $31,05 \pm 2,00^{\mathrm{b}}$ & $1,22 \pm 0,09^{d}$ \\
\hline $\mathrm{T} 2$ & $38,89 \pm 1,00^{\mathrm{a}}$ & $1,37 \pm 0,09^{\mathrm{cd}}$ \\
\hline T3 & $39,61 \pm 1,53^{\mathrm{a}}$ & $1,45 \pm 0,07^{\mathrm{c}}$ \\
\hline $\mathrm{T} 4$ & $40,48 \pm 1,53^{\mathrm{a}}$ & $1,55 \pm 0,16^{\mathrm{bc}}$ \\
\hline T5 & $40,68 \pm 3,21^{\mathrm{a}}$ & $1,75 \pm 0,04^{\mathrm{ab}}$ \\
\hline T6 & $40,68 \pm 4,63^{a}$ & $1,92 \pm 0,11^{\mathrm{a}}$ \\
\hline $\mathrm{T} 7$ & $35,89 \pm 1,00^{\mathrm{ab}}$ & $1,75 \pm 0,17^{\mathrm{ab}}$ \\
\hline $\mathrm{F}$ & $*$ & $*$ \\
\hline $\mathrm{CV}(\%)$ & 3,3 & 4,3 \\
\hline
\end{tabular}

(*) khác biệt ở múc ý nghĩa thống kê 5\%. Trong cùng 1 cột, các chũ số theo sau số có cùng mẫu tự giống nhau thì khác biệt không có ý nghĩa theo phép thủ Duncan.

T1: Giai đoan 10 ngày sau khi cắt, T2: Giai đoạn 15 ngày sau khi cắt, T3: Giai đoạn 20 ngày sau khi cắt, T4: Giai đoạn 30 ngày sau khi cắt, T5: Giai đoạn 40 ngày sau khi cắt, T6: Giai đoạn 50 ngày sau khi cắt, T7: Giai đoạn 60 ngày sau khi cắt.

CV (\%): hệ số biến thiên, SD: độ lệch chuẩn.

Năng suất là chỉ tiêu quan trọng để đánh giá khả năng sinh trưởng và chất lượng cỏ. Theo Nguyễn Thị Hồng Nhân (2010), chỉ tiêu về năng suất chất xanh là yếu tố quan trọng để đánh giá loại thức ăn thích hợp cho gia súc. Năng suất chất xanh cao càng mang lại hiệu quả kinh tế cho nông hộ. Năng suất chất xanh có tương quan với số chồi và $\mathrm{CCC}$ (Nguyễn Văn Hớn \& Võ Ái Quấc, 2007). Số liệu năng suất chất xanh của cỏ Lông tây được trình bày ở Hình 1. 


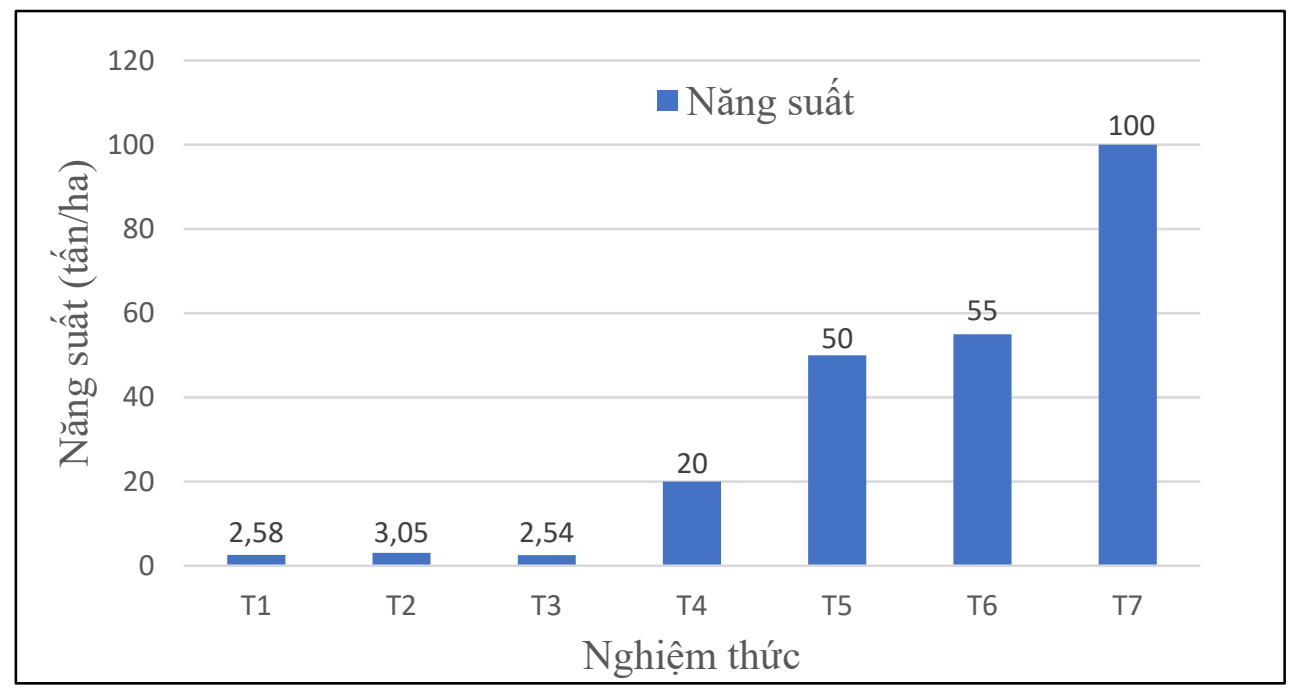

Hình 1. Năng suất chất xanh (tấn/ha/năm) của cỏ Lông tây thí nghiệm

Kết hợp kết quả của biểu đồ và các số liệu phân tích về số chồi, đặc điểm sinh trưởng của thân và lá có thể kết luận năng suất chất xanh của cỏ Lông tây lệ thuộc vào các giai đoạn sinh trưởng. Giai đoạn 1 (T1 đển T3) là giai đoạn cây non, cây tập trung cho sự tái sinh chồi, cây lấy dinh dưỡng từ đất để tạo chồi mới, hình thành thân và tạo lá do đó năng suất thấp nhất. Giai đoạn 2 (T4 đến T6) là giai đoạn kéo dài lóng và tăng diện tích lá, cây phát triển mạnh cả về chiều cao, ĐKT và dài rộng lá. Năng suất ở giai đoạn này tăng đáng kể so với giai đoạn 1 (tăng hơn 18 lần). Giai đoạn 3 là giai đoạn sinh trưởng chậm ở nghiệm thức T7 (60 ngày trở về sau), tại giai đoạn này, $\mathrm{DKT}$ và diện tích lá ngưng tăng trưởng, tuy nhiên năng suất chất xanh là cao nhất với 100 tấn/ha/năm, tương ứng với năng suất chất khô là 19,19 tấn/ha/năm (khi vật chất khô là 19,19\%). Như vậy, ngoài các yếu tố sinh trưởng biểu hiện ở hình thái, năng suất của cỏ Lông tây còn phụ thuộc vào các chất tích luỹ và cấu trúc tế bào, cấu trúc mô bên trong cây.

\subsection{Khảo sát các đặc điểm giải phẫu}

Thức ăn xanh chiếm tỷ lệ cao trong khẩu phần của nhóm loài động vật nhai lại vì chứa nhiều nước và chất xơ. Đối với động vật nhai lại, thức ăn xanh dễ tiêu hóa, có tính ngon miệng cao, tuy nhiên, do hạn chế dung tích đường tiêu hóa nên con vật không ăn được nhiều (Lê Đức Ngoan và ctv., 2006). Các thành phần xơ thô làm thay đổi tỷ lệ tiêu hóa của thức ăn. Do đó, để chọn thức ăn phù hợp cho gia súc cần quan tâm đến hàm lượng này (Lê Đức Ngoan và ctv., 2005). Đối với cỏ Lông tây, lá có tính ngon miệng cao nhưng giảm ở thân và cỏ già. Tỷ lệ tiêu hoá chất xơ cũng biến động, ở lá trong khoảng 65$80 \%$, cành ở ngọn là $55-65 \%$ và giảm xuống $35-45 \%$ ở ngọn già (Lê Đức Ngoan và ctv., 2006). Theo Van Soest et al. (1991), vách tế bào là thành phần chính cấu tạo nên chất xơ. Chất xơ càng nhiều, tế bào thực vật càng cứng, khó phá vỡ, khó tác dụng với enzyme tiêu hóa và tỉ lệ tiêu hoá cũng giảm. Nghiên cứu này sử dụng phương pháp nhuộm vách tế bào và tiến hành khảo sát cấu trúc vi phầu của cỏ Lông tây. Dựa vào các kết quả khảo sát về sinh trưởng của các cơ quan sinh dưỡng và năng suất, các nghiệm thức $\mathrm{T} 2$ (đại diện giai đoạn 1), T4 (đại diện giai đoạn 2) và T7 (đại diện giai đoạn 3 ) được chọn để đánh giá mối quan hệ giữa hình thái-giải phẫu và năng suất-chất lượng trong từng giai đoạn đặc trưng; từ đó có thêm dữ liệu để đánh giá và xác định các khoảng thời gian thu hoạch cỏ một cách hợp lý hơn. 
Giải phẫu thân

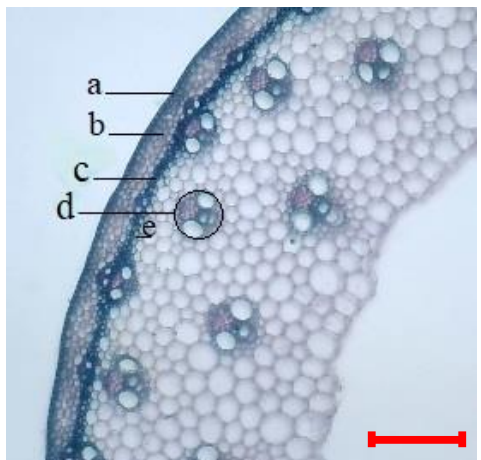

T2 (15 ngày)

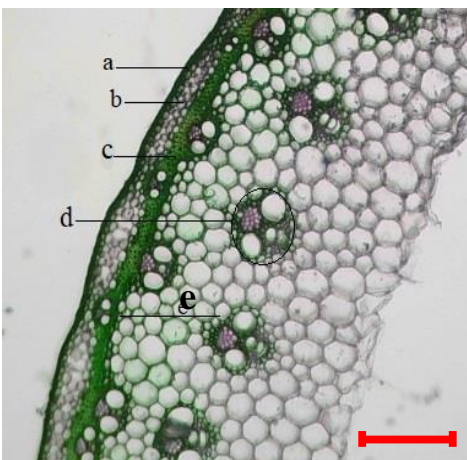

T4 (30 ngày)

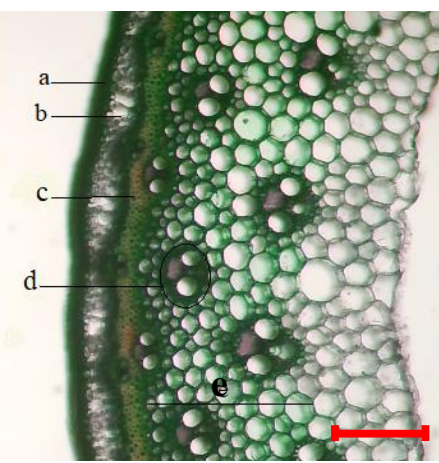

T7 (60 ngày)

Hình 2. Vi phẫu mặt cắt ngang thân trưởng thành của cỏ Lông tây (vật kính 4X)

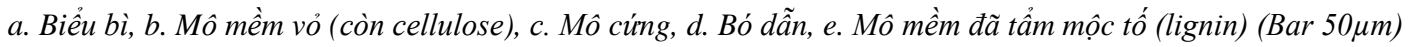

Cấu trúc giải phẫu thân cỏ Lông tây tại các thời điểm 15 ngày, 30 ngày và 60 ngày được thể hiện ở Hình 2. Hình ảnh vi phẫu cho thấy các đặc điểm chung đại diện cho cấu trúc cây một lá mầm dạng thân thảo, từ ngoài vào gồm: tế bào biểu bì (a), mô mềm vỏ (b), mô cứng (c), các bó dẫn (bó libe-gỗ) (d), mô mềm tẩm mộc tố (e). Do không có cấu trúc thứ cấp nên các điểm khác biệt nhận thấy ở 3 vi phẫu là sự dày lên và sự tẩm thêm mộc tố (lignin) ở vách tế bào. Lignin là một trong những thành phần chính của vách tế bào thực vật tham gia tạo chất xơ (Liu et al., 2018). Các mô có sự khác biệt về độ dày do tẩm thêm lignin được đo đếm, kết quả được trình bày ở Bảng 7.

\section{Bảng 7. Chỉ tiêu giải phẫu thân cỏ Lông tây qua các giai đoạn sinh trưởng}

\begin{tabular}{lrrrrr}
\hline Chỉ tiêu & T2 & T4 & T7 & F CV (\%) \\
\hline Diện tích bó dẫn \pm SD $\left(\mu m^{2}\right)$ & $11.216,98 \pm 449,90^{\mathrm{b}}$ & $10.638,88 \pm 460,01^{\mathrm{b}}$ & $14.855,30 \pm 114,52^{\mathrm{a}}$ & $*$ & 6,1 \\
\hline Mô mềm tầm mộc tố $\pm \mathrm{SD}(\mu \mathrm{m})$ & $40,89 \pm 4,64^{\mathrm{b}}$ & $69,27 \pm 9,19^{\mathrm{b}}$ & $296,34 \pm 26,02^{\mathrm{a}}$ & $*$ & 9,4 \\
\hline Biểu bì̀ $\pm \mathrm{SD}(\mu \mathrm{m})$ & $11,20 \pm 0,49^{\mathrm{a}}$ & $12,75 \pm 0,98^{\mathrm{a}}$ & $12,67 \pm 1,01^{\mathrm{a}}$ & $\mathrm{ns}$ & 7,9 \\
Mô mềm $\pm \mathrm{SD}(\mu \mathrm{m})$ & $54,38 \pm 2,40^{\mathrm{b}}$ & $65,99 \pm 4,73^{\mathrm{b}}$ & $97,54 \pm 15,55^{\mathrm{a}}$ & $*$ & 10,4 \\
Mô cứng $\pm \mathrm{SD}(\mu \mathrm{m})$ & $30,78 \pm 5,26^{\mathrm{b}}$ & $29,68 \pm 1,47^{\mathrm{b}}$ & $63,39 \pm 1,16^{\mathrm{a}}$ & $*$ & 8,2 \\
\hline
\end{tabular}

(*) khác biệt ở mức ý nghĩa thống kê 5\%. Trong cùng 1 hàng, các chĩ số theo sau số có cùng mẫu tư giống nhau thì khác biệt không có ý nghĩa theo phép thử Duncan.

T2: Giai đoạn 15 ngày sau khi cắt, T4: Giai đoạn 30 ngày sau khi cắt, T7: Giai đoạn 60 ngày sau khi cắt, CV (\%): hệ số biến thiên, SD: độ lệch chuẩn.

Số liệu của các chỉ tiêu tại Bảng 7 đều có sự khác biệt ý nghĩa thống kê $(\mathrm{p}<0,05)$ ngoại trừ chỉ tiêu về biểu bì, kích thước của các tế bào biểu bì ở các nghiệm thức $\mathrm{T} 2, \mathrm{~T} 4$ và $\mathrm{T} 7$ có giá trị tương đương nhau dao động từ $11,20 \mu \mathrm{m}$ đến $12,75 \mu \mathrm{m}$. Độ dày lớp tế bào biểu bì ít thay đổi và không ảnh hưởng nhiều đến chất lượng của cỏ. Quan sát các phẫu diện sau khi nhuộm màu, các tế bào có vách tẩm lignin (có màu xanh) tăng dần từ nghiệm thức $\mathrm{T} 2$ đến $\mathrm{T} 7$. Tuy nhiên, số liệu nghiệm thức $\mathrm{T} 2$ và $\mathrm{T} 4$ khác biệt không có ý nghĩa thống kê $(\mathrm{p}<0,05)$ khi so sánh với nhau, cụ thể số liệu về diện tích bó dẫn $\mathrm{T} 2$ và $\mathrm{T} 4$ lần lượt là $11216,98 \mu \mathrm{m}^{2}$ và $10638,88 \mu \mathrm{m}^{2}$; trong khi đó, nghiệm thức $\mathrm{T} 7$ có diện tích lớn nhất đạt giá trị $14855,30 \mu \mathrm{m}^{2}$. Kích thước mô mềm có vách tẩm mộc tố (lignin) tăng dần tương quan thuận với thời gian trồng và đạt kích thước lớn nhất ở nghiệm thức $\mathrm{T} 7$ với $296,34 \mu \mathrm{m}$. Trong khi nghiệm thức $\mathrm{T} 2$ và $\mathrm{T} 4$ chỉ đạt lần lượt $40,89 \mu \mathrm{m}$ và $69,27 \mu \mathrm{m}$. Tương tự đối với kích thước của mô mềm và mô cứng, nghiệm thức T7 luôn đạt giá trị cao nhất với kích thước lần lượt là $97,54 \mu \mathrm{m}$ và $63,39 \mu \mathrm{m}$. Hai nghiệm thức T2 và $\mathrm{T} 4$ luôn ở mức thấp hơn, giữa hai nghiệm thức này không có sự khác biệt ý nghĩa thống kê được tìm thấy khi so sánh với nhau. Điều này chứng minh giai đoạn 15 ngày (nghiệm thức T2) là giai đoạn tế bào sinh trưởng; giai đoạn 30 ngày (nghiệm thức T4) là giai đoạn tế bào bắt đầu hình thành độ cứng cho vách tế bào; giai đoạn 60 ngày (nghiệm thức T7) là giai đoạn lignin tẩm vào vách tế bào hoàn toàn, làm tế 
bào già, cứng, làm tăng trọng lượng (năng suất) của cỏ nhưng đồng thời cũng làm tăng hàm lượng chất xơ và chất lượng cỏ sẽ giảm.

\section{Giải phấu lá}

Cơ quan chính của cây thực hiện chức năng quang hợp là lá. Phần mô chủ yếu chứa lục lạp là phiến lá (Nguyễn Bá, 2005). Cấu trúc vi phẫu của cỏ Lông tây được trình bày ở Hình 3 cho thấy cấu trúc của phiến lá không đẳng diện ở mặt trên và mặt dưới của lá. Các mô liên quan đến độ cứng (tạo chất xơ) và khả năng quang hợp của lá đã được đo và kết quả trình bày ở Bảng 8 .

Bảng 8: Chỉ tiêu giải phẫu lá cỏ Lông tây qua các giai đoạn sinh trưởng

\begin{tabular}{|c|c|c|c|c|c|}
\hline Chỉ tiêu & $\mathbf{T 2}$ & T4 & $\mathbf{T 7}$ & & $\mathrm{CV}(\%)$ \\
\hline Độ dày mép lá \pm SD $(\mu \mathrm{m})$ & $69,73 \pm 2,41^{\mathrm{c}}$ & $82,44 \pm 4,73^{b}$ & $102,63 \pm 15,55^{\mathrm{a}}$ & $*$ & 4,3 \\
\hline ch bó dẫn lớn $\pm \mathrm{SD}\left(\mu \mathrm{m}^{2}\right)$ & $16.661,3 \pm 635,00^{c}$ & $19.407,5 \pm 101,76^{\mathrm{b}}$ & $30.537,3 \pm 112,90^{\mathrm{a}}$ & $*$ & 5,2 \\
\hline Diện tích bó dẫn nhỏ $\pm \mathrm{SD}\left(\mu \mathrm{m}^{2}\right)$ & $2.010,97 \pm 139,32^{\mathrm{b}}$ & $2.388,89 \pm 123,96^{\mathrm{b}}$ & $2.913,96 \pm 186,05^{\mathrm{a}}$ & * & 4,4 \\
\hline $\mathrm{y}(\mathrm{hạ} \mathrm{bì)} \pm \mathrm{SD}(\mu \mathrm{m})$ & $63,44 \pm 3,97^{\mathrm{c}}$ & $69,16 \pm 2,05^{\mathrm{b}}$ & $94,55 \pm 0,56^{\mathrm{a}}$ & * & 2,4 \\
\hline & $80,39 \pm 9,63^{b}$ & $72,33 \pm 1,56^{\mathrm{b}}$ & $94,23 \pm 1,14^{\mathrm{a}}$ & $*$ & 3,5 \\
\hline Mô cứng (biểu bì dưới $) \pm \mathrm{SD}(\mu \mathrm{m})$ & $75,32 \pm 3,44^{\mathrm{b}}$ & $74,02 \pm 2,23^{b}$ & $94,93 \pm 2,06^{\mathrm{a}}$ & $*$ & 2,5 \\
\hline
\end{tabular}

(*) khác biệt ở mức ý nghĩa thống kê 5\%. Trong cùng 1 hàng, các chũ số theo sau số có cùng mẫu tụ giống nhau thì khác biệt không có ý nghĩa theo phép thư Duncan.

T2: Giai đoạn 15 ngày sau khi cắt, T4: Giai đoạn 30 ngày sau khi cắt, T7: Giai đoạn 60 ngày sau khi cắt. $C V(\%)$ : hệ số biến thiên, SD: độ lệch chuẩn.

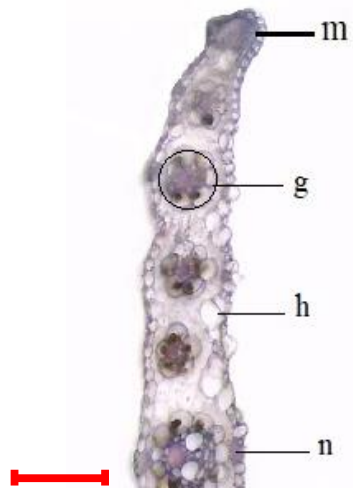

T2 (15 ngày)

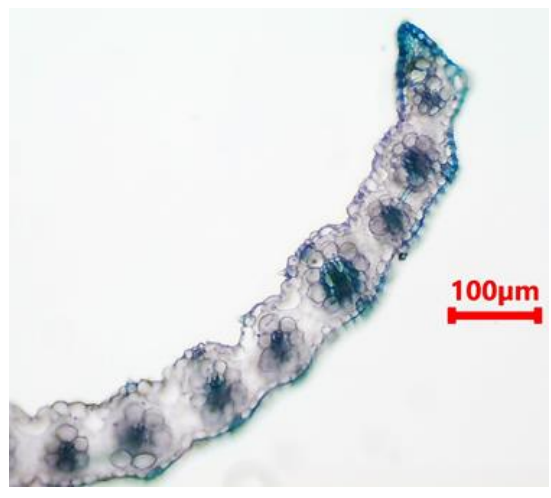

T4 (30 ngày)

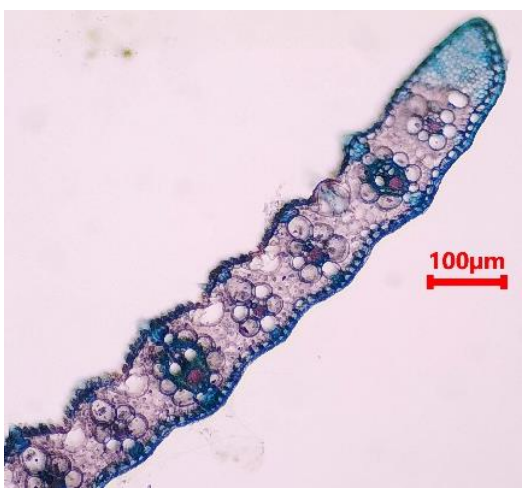

T7 (60 ngày)

\section{Hình 3. Vi phẫu mặt cắt ngang lá cỏ Lông tây (vật kính 10X)}

g. Bó dẫn; h. Mô dầy (hạ bì); m. Mô cúng (ở mép lá); n. Mô cúng (ở dưới biểu bì)

Quá trình sinh trưởng và phát triển lá của cỏ Lông tây từ 15 ngày đến 60 ngày tuổi (Hình 3 ) cho thây mô dày ở mép lá giai đoạn 15 ngày (T2) đã tẩm thêm lignin trở thành mô cứng ở giai đoạn 60 ngày, làm mép lá trở nên cứng hơn. Tương tự, mô dày dưới hạ bì và mô cứng của bó dẫn (nằm giữa bó dẫn với biểu bì trên/biểu bì dưới) cũng được tẩm thêm lignin. Cụ thể, độ dài mép lá (có tẩm lignin) lớn nhất ở nghiệm thức T7 với $102,63 \mu \mathrm{m}$ và độ dài mép lá thấp nhất là $69,73 \mu \mathrm{m}$ ở nghiệm thức T2. Diện tích bó gỗ lớn và bó gỗ nhỏ đạt giá trị lớn nhất ở nghiệm thức T7 lần lượt là $30537,28 \mu \mathrm{m}$ và $2913,96 \mu \mathrm{m}$. Tương tự, kích thước mô cứng (ở biểu bì dưới và biểu bì trên), mô dày (hạ bì) ở nghiệm thức T7 cao nhất. Các chỉ tiêu ở hai nghiệm thức $\mathrm{T} 2$ và $\mathrm{T} 4$ không khác biệt có ý nghĩa thống kề $(\mathrm{p}>0,05)$ cho tất cả các mô khi so sánh với nhau. Như vậy, ở nghiệm thức T7 các mô có vách tẩm thêm lignin chiếm diện tích lớn trong phiến lá. Khi vách tế bào tẩm lignin, các quá trình trao đổi chất giảm, làm ảnh hưởng đến khả năng đồng hóa từ đó làm giảm quá trình quang hợp (Raven et al., 2013). Mặt khác, sự biến đổi này có thể làm chất lượng của lá thay đổi do tăng hàm lượng chất xơ. Việc tiến hành thu hoạch tại thời điểm này có thể cho năng suất cao nhưng không nên tiếp tục kéo dài vì ảnh hưởng đến chất lượng của cỏ. 


\section{KẾT LUẬN}

Dựa vào các đánh giá về đặc điểm của thân, lá và khả năng tái sinh có thể chia sự sinh trưởng và phát triển của cỏ Lông tây thành 3 giai đoạn: (1) Giai đoạn sau khi cắt đến 20 ngày, là giai đoạn tái sinh chồi, hình thành thân và tạo lá; (2) Giai đoạn từ 30 ngày đến 50 ngày sau khi cắt là giai đoạn phát triển mạnh của cơ quan sinh dưỡng; (3) Giai đoạn 60 ngày trở về sau là giai đoạn sinh trưởng chậm. Kết hợp kết quả giữa khảo sát đặc điểm sinh trưởng và vi phẫu, thời gian thu hoạch phù hợp là từ 30 ngày đến 50 ngày ( $T 4, T 5$ và $T 6$ ), giai đoạn 60 ngày (T7) trở về sau các mô tẩm lignin chiếm phần lớn cấu trúc mô, làm hàm lượng chất xơ tăng, lá giảm quá trình đồng hoá, thu hoạch cỏ tại thời điểm này có thể cho năng suất cao nhưng phẩm chất kém hơn so với các thời điểm trước đó.

\section{LỜI CẢM TẠ}

Đề tài này được tài trợ bởi Dự án Nâng cấp Trường Đại học Cần Thơ VN14-P6 bằng nguồn vốn vay ODA từ Chính phủ Nhật Bản.

Cảm ơn sinh viên Hà Nhân Ái, Lớp Nông học Khóa 43, Trường Đại học Cần Thơ và nghiên cứu viên Nguyễn Hửu Thiện công tác tại Bộ môn Khoa học Đất, Khoa Nông nghiệp, Trường Đại học Cần Thơ đã hỗ trợ thực hiện nghiên cứu này.

\section{TÀI LIỆU THAM KHẢO}

Alam, M., Haque, M., Sumi, K., \& Ali, M. (2015). Proximate composition of para-grass (Brachiaria mutica) produced in integrated fish-fodder culture system. Bangladesh Journal of Animal Science, 44(2), 113-119. https://doi.org/10.3329/bjas.v44i2.26011

Bridgemohan, P., Singh, K., \& Lewis, R. (2015). Biology and management of invasive terrestrial weed species of Trinidad. The University of Trinidad and Tobago.

Cục Chăn nuôi. (2020). Tình hình chăn nuôi năm 2019. http://nhachannuoi.vn/tinh-hinh-channuoi-nam-2019.

Crang, R., Lyons-Sobaski, S. \& Wise, R. (2019). Plant anatomy: A concept-based approach to the structure of seed plants. Springer US.

Dong, N.T.K., Thu, N.V., Ogle, B. \& Preston, T.R. (2008). Effect of supplementation level of water spinach (Ipomoea aquatica) leaves in diets based on para grass (Brachiaria mutica) on intake, nutrient utilization, growth rate and economic returns of crossbred rabbits in the Mekong Delta of Vietnam. Livestock Research for Rural Development, 20(9), Article 144. http://www.lrrd.org/lrrd20/9/kdon20144.htm.
Duru, M., \& Ducrocq, H. (2000). Growth and senescence of the successive grass leaves on a tiller. Ontogenic development and effect of temperature. Annals of Botany, 85(5), 635-643. https://doi.org/10.1006/anbo.2000.1116

Dwari, S., \& Mondal, A.K. (2011). Systematic studies (morphology, anatomy and palynology) of economically viable grass Brachiaria mutica (Forsskil) Stapf in Eastern India. African Journal of Plant Science, 5(5), 296-304. https://doi.org/10.5897/AJPS.9000244

Evert, R.F., Eichhorn, S.E. \& Raven, P.H. (2013). Biology of plants. W.H. Freeman and Company Publishers.

Frank, A.B. (1996). Evaluating grass development for grazing management. Rangelands, 18(3), 106-109.

Lê Đức Ngoan, Nguyễn Xuân Bả \& Nguyễn Hữu Văn. (2006). Thức ăn cho gia súc nhai lại trong nông hộ ở miền Trung. Nhà xuất bản Nông nghiệp, Hà Nội.

Liu, Q., Luo, L., \& Zheng, L. (2018). Lignins: biosynthesis and biological functions in plants. International Journal of Molecular Sciences, 19(2), 335.

Lopes, M.N., Pompeu, R.C.F.F., Cândido, M.J.D., de Lacerda, C.F., da Silva, R.G., \& Fernandes, F.R.B. (2011). Growth index in massai grass under different levels of nitrogen fertilization. Revista Brasileira de Zootecnia, 40(12), 26662672. https://doi.org/10.1590/S151635982011001200008

Lưu Hữu Mãnh, Nguyễn Nhựt Xuân Dung \& Trần Phùng Ngỡi. (2007). Ảnh hưởng của khoảng cách trồng lên đặc tính sinh trưởng và tính năng suất của cỏ mồm (Hymenachne acutigluma) và cỏ Lông tây (Brachiaria mutica). Tạp chí khoa hoc Trường Đại hoc Cần Tho, 7, 49-57.

NCERT. (2005). Biology textbook for Class XI. National Council of Educational Research and Training, India.

Neville, F. M. A. \& Marbora, F.R.S.A. F. (2007). Tree Morphology - A branch of arboriculture from renaissance to raimbault [seminar]. Tree Morphology (Part 2), Theory \& Practice, Diagnostics \& Management, University of the West of England, Bristol.

Nguyễn Bá. (2005). Hình thái học thực vật. NXB Giáo dục Hà Nội.

Nguyễn Bá Lộc. (2011). Giáo trình Sinh lý thực vật. NXB Giáo dục Thái Nguyên.

Nguyễn Nhựt Xuân Dung, Lưu Hữu Mãnh \& Nguyễn Thị Mộng Nhi. (2007). Thành phần hóa học và giá trị dỉnh dưỡng của một số giống cây thức ăn gia súc họ hòa thảo và họ đậu trồng tại 
Thành phố Cần Thơ. Tạp chi Khoa học Truờng Đại hoc Cần Tho, 7, 183-192.

Nguyễn Thị Hòa Bình, Ngô Thị Thùy, Bùi Huynh Doanh, Đặng Thái Hải, Nguyễn Thị Hằng \& Bùi Quang Tuấn. (2017). Năng suất và giá trị dinh dưỡng của cỏ Taiwanese napier nhập từ Thái Lan trồng tại Học viện Nông nghiệp Việt Nam. Tạp chí khoa học Nông nghiẹp Việt Nam, 15(4), 462-470.

Nguyễn Thị Hồng Nhân. (2010). Nghiên cứu xác định bộ giống cỏ Hòa thảo, năng suất, chất lượng cao phù hợp với vùng sinh thái Tây Nam Bộ. Tạp chí Khoa học Chăn nuôi, 7, 65-72.

Nguyễn Văn Hớn \& Võ Ái Quấc. (2007). Khảo sát đặc tính sinh trưởng, năng suất và giá trị dinh dưỡng của cỏ Vetiveria zizanioides với thời gian thu hoạch khác nhau. Tạp chi khoa hoc Truờng Đại hoc Cần Tho; 8, 125-131.

Phan Thị Phương Nhi \& Trần Thị Hương Sen. (2017). Nghiên cứu sinh trưởng, phát triển và năng suất của một số giống lúa có khả năng chịu hạn. Khoa học Nông nghiệp, 21(10), 15-19.

Rechenthin, C.A. (1956). Elementary morphology of grass growth and how it affects utilization. Journal of Range Management, 9(4), 167-170.

Rumokoy, L.J. M., \& Toar, W.L. (2014). The forage production of Brachiaria mutica under coconut tree canopy. Lucrări Ştiinţifice - Seria Zootehnie, 62, 131-134.

Serra, A.B., Serra, S.D., Fujihara, M., Orden, E.A., Cruz, L.C., Ichinohe, T., \& Fujihara, T. (1996). Monthly nutrient variation of paragrass (Brachiaria mutica) and stargrass (Cynodon plectostachyum) collected from pastures grazed by goats. Asian-Australasian Journal of Animal Sciences, 9(2), 203-210. https://doi.org/10.5713/ajas.1996.203

Sumardi, I. \& Wulandari, M. (2010). Anatomy and morphology character of five Indonesian banana cultivars (Musa spp.) of different ploidy level. Biodiversitas, 11(4), 167-175.
Sumolang, C., Rumokoy, L., Liwe, H., Telleng, M. \& Toar, W.L. (2020). Application of dry-mixmanure layer on production of Brachiaria mutica cultivated in unrestricted sunlight area. Scientific Papers. Series D. Animal Science. LXIII(2), 151-156.

Taiz, L. \& Zeiger, E. (2002). Plant physiology ( $3^{\text {rd }}$ ed.). Sinauer Associates Inc.

Trần Đại Nghĩa. (2018). Tài liệu huoóng dẫn về nông nghiệp thông minh với biến đổi khi hậu 1. Hà Nội: Nhà xuất bản Nông nghiệp.

Từ Trung Kiên. (2011). Nghiên cứu năng suất, chất luợng và hiệu quả sủ dụng một số giống cỏ hòa thảo nhập nội trong chăn nuôi bò thịt. Luận án tiến sĩ nông nghiệp Chuyên ngành Chăn nuôi động vật. Đại học Thái Nguyên.

Upton, R., Graff, A., Jolliffe, G., Länger, R., \& Williamson, E. (2016). American herbal pharmacopoeia - Botanical pharmacognosymicroscopic characterization of botanical medicines. CRC Press. https://doi.org/10.1201/b10413

Van Soest, P.J., Robertson, J.B., \& Lewis, B.A. (1991). Methods for dietary fiber, neutral detergent fiber, and nonstarch polysaccharides in relation to animal nutrition. Journal of Dairy Science, 74(10), 3583-3597.

Wu, L.L., Liu, Z.L., Wang, J.M., Zhou, C.Y. \& Chen, K.M. (2011). Morphological, anatomical, and physiological characteristics involved in development of the large culm trait in rice. Australian Journal of Crop Science, 5(11), 13561363.

Zemene, M., Mekuriaw, Y., \& Asmare, B. (2020). Effect of plant spacing and harvesting age on plant characteristics, yield and chemical composition of Para grass (Brachiaria mutica) at Bahir Dar, Ethiopia. Scientific papers:Animal Science and Biotechnologies, 53(2), 137-145. 